\title{
A SOCIOLOGICAL VIEW OF SOVEREIGNTY.
}

CHAPTER XII.

\section{INDUSTRAL PROPERTY AND CORPORATIONS.}

THE third original institution, or set of institutions, from which the state has sprung, was private property in slaves, serfs, land, and capital, or the industrial institution per se. Throughout social evolution during the empiric stage this institution was subordinate to the overshadowing institutions of the family, the monarchy, the church. But since the emergence of the reflective stage and its abolition of slavery and serfdom, the industrial has taken a new and derived form, a change analogous to that which occurred in religion in the transition from the ethnic to the ethical, and in the state in the transition from absolutism to constitutionalism. These derived institutions are the merchants' and manufacturers' guilds and the more recent business corporation.

The persuasive basis of industry is originally closely bound with the coercive basis of organization, both being grounded on the necessity of subduing nature to gain a livelihood. But in the empiric stage coercion was corporal-the direct ownership of slave and serf. Consequently labor was degraded and despised, and those whose lot it was felt no particular devotion to it. But in the reflective stage, with the freedom of labor, with inventions, machinery, and industrial technique, industry acquires an interest in itself and arouses a devotion which is susceptible to the sanctions of persuasion. The love of work is the persuasive basis of industry. Work has an interest for its own sake, and also an ulterior interest as a means to the sustaining of all the other institutions. A free man works because he finds an interesting outlet for his energies, and because he wishes to support wife, children, preacher, government. But in so far as this ulterior end is not voluntary but compulsory, in so far as this love of work is overshadowed by the necessities of the worker, the basis 
is not persuasive, but coercive, and where the latter element still exists it chokes the persuasive element and gives character to the institution. It is the gradual extraction of coercion from industry and its absorption by the state that permits this institution to be separated out from the others and established upon its own persuasive motive, the love of work.

The material basis, from the very nature of the institution, is more inclusive in industry than in any other institution. Industry is concerned primarily with the material of nature, fitting it for use in all institutions. It produces food, clothing, and shelter for wife and children; weapons and munitions for the state; cathedrals for the church; ballot paper for political parties. It thus prepares the primary material basis to which the other institutions add their own peculiar increment of value. It is partly for this reason that in the empiric stage, when production is direct and not yet based on the roundabout methods of accumulated capital, the industrial institution is not yet differentiated out from under the domestic, the military, and the ecclesiastical institutions. Capital consists of tools in place of machinery; land is more abundant than population; and consequently the material basis of industry does not have an independent importance and value. It is laborers who are scarce rather than land and machinery, and consequently industry is built upon slavery and serfdom rather than upon property in land and capital. ${ }^{x}$ In the reflective period, however, with its wage system and oversupply of labor relative to land and capital, the latter becomes the basis of a newly differentiated institution, the industrial.

The organization of industry and its tendency to monopoly and centralization have the same basis and follow the same laws as those we have seen in other institutions. Yet the distinction between the empiric and reflective stages must be noted. In the former stage, as already stated, industry had not acquired its separate institution, but was subordinate mainly to the political institution. Therefore, as the latter developed toward centralization,

I The disproportionate importance given to this principle by Loria, expanding on the suggestion of Henry George, cannot be accepted. He overlooks the equal importance of religious and moral beliefs. See translation by KEASBEy, Loria, The Economic Foundations of Society. 
so did industry centralize with it. The absolute monarch was private proprietor, not only of the land and vassals, but also of all the slaves and serfs belonging to the latter. Centralization was political, not industrial. Consequently in the later development of the state whereby subordinate classes gained partnership with the monarch and introduced order and right into coercion, the rights acquired were not peculiarly industrial, but primarily political. Freedom of labor is a political privilege. The right of free industry is the right to be free from governmental obstructions in the way of setting up an independent establishment and buying in the cheapest market and selling in the dearest. The right of free movement and free employment is the right to be free from arbitrary political obstruction in seeking employment. The right of property is the right of every individual, regardless of rank, learning, political influence, or other obstruction, to get and keep such property as he can. These are all primarily political privileges, and consist in the removal of those restrictions which the rulers had imposed directly on individuals and classes.

It is often asserted that slavery and serfdom disappeared, not because of state prohibition, but primarily through the economic fact of the wastefulness of coerced labor in competition with voluntary labor. This view is undoubtedly true. As already stated, only when useful objects, be they tools, animals, women, men, land, saints' relics, or public franchises, come to be recognized as scarce with reference to the existing density and volume of population, does their significance for self and their capacity for coercion rise into consciousness with sufficient clearness to invite men to appropriate them as private property. And when the increasing population and wealth production have transferred scarcity to other factors, then is the motive for appropriation also transferred. But while this may cause the disappearance of slavery and serfdom, it is not enough to bring about the positive rights of freedom. Economic causes alone would abolish serfdom, but would not prevent the substitution of a caste system like that of India. It required the positive interference of the state in the creation of legal rights, such as free 
industry, free movement, free employment, free ownership of property, to enable individuals from the serf caste not only to be free from direct coercion, but also to break into the hitherto exclusive ranks of the ruling castes, and to share their industrial privileges. In China, too, with a weak state, slavery has run for centuries alongside freedom. But the European or American state, with its doctrines of right and its partnership of the capitalist and wage-earning classes, has both forcibly deprived the original slave- and serf-holding aristocracies of their private property in men, and has also given the latter equal privileges with the former, and in so doing has reshaped the industrial institution in such a way that indirect coercion and persuasion mainly, instead of direct coercion, must be relied upon to induce work and to create wealth. By the abolition of slavery and serfdom all persons are made the property of the state instead of the property of private owners, and the state, using its coercive power as it sees fit, has adjusted them to each other in their work according to its ideas of right, constituting the familiar substantive rights of life, property, free contract, free movement, free industry, free use of public property and the gifts of nature, etc. Caprice is thus largely excluded from industry, and order and security take its place-indispensable conditions for that immense increase of production required by the increase of population, and producible only through methods of persuasion.

The state in the reflective period, thus extracting direct coercion from property owners, prepared the way for the evolution of the industrial institution upon its own material basis. It did this by breaking down the restrictions which subordinate industry to politics and religion, thus making possible new associations of men for industrial purposes alone. The rights of freedom made industry fluid, and prepared it to recrystallize around its own persuasive and material basis. The material basis thus prepared was private property in land and capital, which henceforth was to be free of acquisition to all, and transferable. Here is a new basis for the industrial institution, enabling it to be separated out from other institutions and to 
develop toward monopoly and centralization by means of its own indirect coercion, the privative sanctions. This development took successively two forms, the guild and the corporation.

First, as to the guilds. Along with the freedom of labor which resulted from economic and legal changes went the growth of absolutism ; and the monarch, in order to strengthen himself against his nobility, introduced what may be called the democratization of property. The fact and concept of property originated as the possession of a narrow and aristocratic class. Serfs, slaves, and subordinates were not considered as capable of holding property in their own right. The mediæval guilds of merchants and manufacturers, having their origin in the necessity of association on the part of the newly freed serfs, and gradually gaining through their organization a recognition from the king, secured from the latter for each of their members the right of private property in tools, lands, and family. This democratization consisted simply in the right to buy, sell, and give their own tools and lands in trade and their daughters in marriage, just as the feudal lords did with their property.

These guilds, originating as the voluntary associations of free men, secured in time, through the further growth and stengthening of their organization, the exclusive jurisdiction, not only of commerce and manufactures, but also of local government, within their respective areas, as well as a share in the national government. The last came about as follows: Their delegates or headmen, from time to time, met in national convention, or went as a lobby to the meetings of the king and his grand council, in order to secure special privileges for their members. This convention or lobby was finally legalized and incorporated with delegates from the smaller landowners, and became a branch of the state, the house of commons. The guilds themselves in their local areas were granted again and again certain sovereign prerogatives - the right to tax themselves, to appoint and name the governmental officers in the locality, to adopt and enforce ordinances. Gradually by this process of legalization they became intrinsic parts of the structure of sovereignty. The sovereign merely took those forms 
of organization which had sprung up as private associations through struggle and survival, and had shown by the fact of survival their strength and fitness, and then filled them with political functions. Their structure, that is, the organization of their coercive sanctions, was private and competitive in its origin and growth. It became public simply by being legally recognized as an organization and intrusted with public functions. Later, through the simple device of extension of the suffrage, subordinate and hitherto excluded classes, living in the area governed by the organization, were admitted to partnership in determining its will. This may be called the socialization of property and institutions. The democratization of institutions consisted in breaking up the centralized form which had resulted from survival, and creating small copies of it, each with similar unrestricted powers of private dominion. The socialization of institutions consists in introducing the subordinate classes into partnership with the hitherto absolute proprietor. The family was democratized when polygamy was outlawed, and slaves and serfs were guaranteed possession and control of their wives and children. The family was socialized when the wife and children were granted the right to veto the arbitrary commands of the head of the family and so were made partners with him. Political parties were democratized through the guaranteed right of free assemblage, free speech, and free nomination and election of candidates, whereby any group of persons could organize a party if they could persuade enough others to join. Parties are being socialized through the legalized ballot and primaries, by which the organization proper is transferred to sovereignty, and the subordinate members are guaranteed approved rights of veto and persuasion within the organization. ${ }^{x}$ Democratization divides and multiplies an institution, restricting its centralizing tendencies, but retains its basis in private property. Socialization transfers it from private property to sovereignty, incorporates its organization into the constitution of the state, fixes the relations of its members to each other against capricious change, and amends it in such ways as

'See following chapter. 
to guarantee certain rights within it to the constituted members. The guilds were a consequence of the democratization of property. Their socialization was effected after the triumph of the exclusive jurisdiction and political power which they attained under private control. This power and jurisdiction, being legally recognized and transferred to sovereignty, was amended in the interest of order and right, and thereby became the structure of city government.

Strangely enough, the guilds, which originated and grew up as industrial associations, ultimately lost their industrial life, while the shell of their organization survived by being filled with political duties. Their fate strikingly illustrates the suffocation which organization, as it approaches perfection, with its increased coercive power, inflicts upon the persuasive principle which animates it. Owing to the restrictions of the guilds, the new industry which arose with the inventions of machinery was compelled to seek new areas and develop a new organization, the corporation.

In the origin of business corporations we find again the freedom of labor and democratization of property which furnished the basis for new associations. Here, also, the principle of coercion with its privative sanctions was the basis of organization. Perfect freedom on the part of the owners of machinery in the employment, payment, discharge, and promotion of those who worked with their machines was the condition of organizing and economizing the forces of each establishment and fitting it to overcome others in the struggle for survival. Again, also, in this struggle, proceeding for the past I50 years, the smaller and weaker establishments have disappeared, and their territory has been occupied by the larger, until, in the United States, where this private competition has been the freest, and where corporations were earliest legalized through general incorporation laws in the place of special charters, the resultant monopoly and centralization have in many industries been accomplished. The state has not only not interfered, but has contributed positively to the process of centralization by its laws creating and protecting business corporations. These corporations, being a species of 
joint property, require for the unity of administration of the coercive sanctions intrinsic in private property a further coercive power on the part of a portion of their stockholders over the remaining portion. A corporation is in law a unity, an artificial person, and by this can only be meant that all stockholders must submit to the controlling interest. The state, without taking ethical questions into account, but merely recognizing the natural unreflective relations which property owners assume to each other, legalized these relations as it found them, and determined the controlling interest in the corporation on the basis of the shares of stock rather than the number of stockholders. The will of the corporation is therefore the will of the owners of a majority of the stock. The process of socialization of these corporations has begun through legislation protecting, or rather creating, rights of the minority stockholders in determining the will of the institution. The state has not gone as far as to obliterate the plutocratic basis, "one share one vote," but it has in some cases, under a new ethical motive, authorized associations to be formed on the humanitarian basis, "one member one vote." These are known as coöperative associations, and the fact that they have not survived in the struggle with corporations shows how difficult it is for the state to create outright the structure of a new institution. Structure is a matter of private, competitive, unethical, coercive survival, and the state can introduce the ethical notions of right into it only after its period of struggle is past and after its monopolistic character has guaranteed immunity from the disciplined organizations based on private coercion. Since the public opinion controlling the state has not yet recognized the inevitable monopoly of corporations and is still busied with plans for their democratization, our search will find as yet but occasional steps toward their socialization. It can only be said that such steps will probably be directed to providing further rights for minority stockholders and to creating rights within the corporation for the laborers employed. The rights of the laborers turn especially upon the right to freedom from capricious employment and discharge, that is, to the introduction of order and right into the structure of the 
institution. In general this may be designated as the "right to employment," and should be distinguished both from the "right to work" advocated by the revolution of 1848 in France and from the socialistic theory of the rights of laborers.

Louis Blanc's advocacy of the "right to work" and the establishment of "national workshops" in I848 recognized intuitively that the right to work depended upon the perfection of organization. Consequently the two planks of the revolutionary platform were the "right to work" and the "organization of labor." The former depended on the latter. But the plan of organization thus ethically preconceived could by no means survive. It was absurdly simple and military. Eleven laborers formed an "escouade" with an "escouadier" at their head, five escouades a brigade with a brigadier, four brigades a lieutenancy, four lieutenancies a company, and as many companies under one chief as were necessary. ${ }^{x}$ Apart from the reputed hostility of the French government which administered these workshops, they, of course, could not have competed with the highly disciplined organization of the "trust" which natural selection has since evolved. The state was here, as with the coöperative association, attempting to create an ethical institution where only a coercive one could survive. The case is different, however, after the final victory of the trust or monopoly. In this case the coercive sanctions have been organized and preserved by the struggle for life, and are fitted to the work in hand. Ethical considerations are now only questions of such structural amendment as will give the laborers security within the perfected and victorious organization. The device of compulsory or legal arbitration, as adopted in Australian colonies, is a step in this direction. Public ownership of monopolies is probable in many cases, but where it has hitherto been adopted the motive has not been mainly the provision of rights for employés, but the improvement and cheapening of the service for the public. Civil-service reform is a crude guaranty of the right to employment in the public service, but it again lacks fitness for industry, since it is an artificial check on the heads of

${ }^{x}$ See Singer, Das Recht auf Arbeit (Wien, I894), p. 44. 
departments imposed by an outside commission, and was created by the state outright on ethical and a priori principles, instead of being developed under the test of survival. In successful private business the general manager has complete power of appointment and removal of subordinates, unhampered by any outside academic board of examiners, and if private industry is transferred to public ownership, this method must be retained. The solution lies in the proper selection of the heads of departments, and in accomplishing this the state or city must imitate the method of private corporations in selecting their general managers and superintendents. ${ }^{x}$ The structure of industry must be incorporated into government exactly as developed by competitive survival, but at the same time must be so amended as to secure the rights of the laborers which are at the time accepted as the ethical purpose of the state.

The right to employment differs from the socialistic theories of labor's rights in that the latter hold that the laborer has the right to the entire product. If this be so, there can be no temporizing with petty claims short of confiscation. But these theories are weak on the economic side, because they do not apprehend the psychological basis of interest; and they are peculiarly naive in their treatment of organization and administration, for, while socialists see the coerciveness of private property, they do not see that coercion is also the basis both of that organization which makes private business successful and of that administration which constitutes government. Coercion has a psychic basis, founded in human nature, and whether it be in

ISee Commons' Pro. Report., New York, i896, pp. 2II-i6. Also report of New York state excise commissioner, I898. The commission, speaking of the amended civil-service law which restricted the state civil-service commission to examinations for "merit" only and gave to the heads of departments authority to hold examinations for "fitness," says, p. 38 : "The results of these examinations were very interesting and instructive, and satisfied me that, except for places requiring technical knowledge, no examination which appears to grade and rate people according to their relative ability for a particular line of work should ever be wholly a paper or written examination; but should be made and personally conducted by people of broad experience, quick perception, and knowledge of human nature, who themselves are thoroughly qualified in the line on which they assume to question and grade candidates." 
public or private hands, it cannot neglect its basis. Now, organization is essential to the right to employment, and socialists, by disdaining administrative problems, fail to comprehend the very nature of the state which they seek to enlarge.

Without considering further the possible details of state control of industry, we can only observe the principle. The growth of monopoly and centralization increases the coercive power of the private owners of industry by strengthening the privative sanctions. All the opportunities for investment and labor being under the control of a single authority, the material penalties inflicted on those who do not obey this authority are unavoidable. But the grounds for private coercive authority having ceased through the cessation of struggle, the state as the coercive institution of society tends to absorb this side of the industrial institution. It constitutes itself the coercive framework of industry within which the persuasive motives operate. This framework consists in the statutes and codes of laws governing property and corporations, the factory laws, the judicial decisions, the administrative methods which determine the relations of producers to each other. The state becomes the framework of industry, just as it becomes the framework of the family and the church. The laws governing property and labor constitute the bulk of its functions, and the legislatures, courts, and executives have been created expressly for, and are busied mainly with, the regulation of this important institution. And here, as with the other two original institutions, we see how the organic nature of the state has grown. It has been differentiated out from the primitive, homogeneous blending of institutions, not by being separated off from society and set out as a kind of envoy extraordinary, whose business it is to treat and arbitrate with foreign states and between private proprietors, but the very differentiation has been at the same time a deepening of the hold of the state and its seizure upon the hidden recesses of society previously autonomous. The state bears the relation to other institutions of structure to function, of organization to life, of machinery to force, of coercion to persuasion.

It is in this very way that the state liberates the industrial 
motives from capricious control and gives security and right to the subordinate members of the institution. The persuasive motives thus freed are greatly strengthened and intensified. Security for investors and minority stockholders stimulates the savings of the masses of the people, increases their thrift, lowers the rates of interest, multiplies the machinery and production of society. The position of laborers is removed from the personal control of those over whom they have, in turn, no control; the amount and kind of their work becomes defined and calculable; each laborer acquires increased scope of self-direction, and his productive powers are called out, not by the fear of deprivation, but by the remuneratory and approbatory sanctions upon which his employers are thenceforth compelled to rely. Useful labor, thus freed from the badge of subjection, becomes a motive in itself, and the industrial institution, like other institutions, is established on its own clarified, persuasive basis, the love of work.

Syracuse UNIVERSITY.

John R. Commons.

[To be continued.] 